\title{
Podsumowanie roku 2019 w niewydolności serca z obniżoną frakcją wyrzutową lewej komory
}

\author{
The summary of the 2019 year in heart failure \\ with reduced ejection fraction
}

\author{
Małgorzata Lelonek
}

Zakład Kardiologii Nieinwazyjnej Uniwersytetu Medycznego w Łodzi

\section{Streszczenie}

Ostatnie lata w niewydolności serca (HF) to czas innowacyjnych terapii. Opublikowanie wyników nowych badań klinicznych spowodowało konieczność usystematyzowania wiedzy i sformułowania praktycznych wskazówek zgodnych z medycyną opartą na dowodach naukowych pochodzących z dużych badań. Z tego powodu w ubiegłym roku opracowano konsensus ekspertów Asocjacji Niewydolności Serca (HFA) Europejskiego Towarzystwa Kardiologicznego. W niniejszym artykule przedstawiono najważniejsze zagadnienia dotyczące niewydolności serca z obniżoną frakcją wyrzutową lewej komory wraz z komentarzem do opublikowanego konsensusu HFA.

Słowa kluczowe: niewydolność serca z obniżoną frakcją wyrzutową lewej komory

Folia Cardiologica 2020; 15, 2: 176-181

\section{Wstęp}

Ostatnie lata w niewydolności serca (HF, heart failure) charakteryzuje znaczny postęp w zakresie farmakoterapii. Od czasu ogłoszenia wytycznych Europejskiego Towarzystwa Kardiologicznego (ESC, European Society of Cardiology) w 2016 roku opublikowano kilka istotnych doniesień. Mając to na uwadze, w ubiegłym roku odbyło się spotkanie ekspertów Asocjacji Niewydolności Serca (HFA, Heart Failure Association) ESC, którego celem było podsumowanie aktualnego stanu wiedzy i postępowania w HF. W niniejszym artykule przedstawiono najważniejsze informacje dotyczące niewydolności serca z obniżoną frakcją wyrzutową lewej komory (HFrEF, heart failure with reduced ejection fraction) wraz z komentarzem do opublikowanego w „European Journal of Heart Failure” w 2019 roku konsensusu ekspertów HFA ESC [1].

\section{Inhibitory kontransportera} sodowo-glukozowego 2

W wytycznych ESC z 2016 roku po raz pierwszy pojawiła się nowa koncepcja farmakoterapii inhibitorami kotransportera sodowo-glukozowego 2 (SGLT2i, sodium-glucose cotransporter 2 inhibitors) w związku z wynikami badania EMPA-REG OUTCOME. Jak wiadomo, badanie to nie było poświęcone pacjentom z HF, ale udokumentowanie w nim korzyści z terapii empagliflozyną przyczyniły się do uwzględnienia leku w lla klasie zaleceń u chorych na cukrzyce typu 2 w celu zapobiegania lub opóźnienia wystąpienia HF i przedłużania życia [2]. Od tego czasu opublikowano kolejne subanalizy badania EMPA-REG OUTCOME, w których w odniesieniu do empagliflozyny udokumentowano obniżenie ryzyka wystąpienia pierwszorzędowego punktu końcowego niezależnie od statusu glikemicznego [3] oraz 
wyjściowego ryzyka sercowo-naczyniowego wyliczonego według Thrombolysis in Myocardial Infarction (TIMI) Risk Score [4]. Poprawę rokowania odnosili chorzy z grupy zarówno wysokiego, jak i niskiego ryzyka. Korzyść kliniczna z terapii empagliflozyną udokumentowano również w zakresie przedłużenia życia we wszystkich grupach wiekowych [5]. Jednakże najwięcej korzyści odnoszą młodzi pacjenci w wieku 45 lat, w przypadku których poprawe przeżycia wyliczono na 4,5 roku.

W kolejnych latach pojawiły się liczne badania z zastosowaniem SGLT2i, w tym między innymi dotyczące empagliflozyny (EMPERIAL, EMPEROR, EMPULSE), dapagliflozyny (DECLARE, DAPA-HF) i kanagliflozyny (CANVAS, CREDENCE). Niektóre z nich już się zakończyły, dlatego we wspomnianym konsensusie informacje o SGLT2i rozszerzono o zastosowanie kolejnych flozyn (z zaleceniem „należy rozważyć”), tj. kanagliflozyny i dapagliflozyny u chorych na cukrzyce typu 2 i schorzenie układu sercowo-naczyniowego lub obciążonych wysokim ryzykiem sercowo-naczyniowym w celu zapobiegania lub opóźnienia wystąpienia HF i hospitalizacji z tego powodu [1]. Natomiast Agencja ds. Żywności i Leków (FDA, Food and Drug Administration) w 2019 roku zatwierdziła nowe wskazanie dla dapagliflozyny - obniżenia ryzyka hospitalizacji z powodu HF u pacjentów z cukrzycą typu 2 i stwierdzonymi chorobami układu sercowo-naczyniowego lub obciążeni wieloma czynnikami ryzyka sercowo-naczyniowego.

Dodatkowym wydarzeniem ubiegłego roku było ogłoszenie podczas kongresu ESC w Paryżu wyników badania DAPA-HF w HFrEF (frakcja wyrzutowa lewej komory [LVEF, left ventricular ejection fraction] $\leq 40 \%$ ), w którym około połowa populacji nie chorowała na cukrzyce [6]. Uczestników poddano randomizacji do dwóch grup: leczonych dapagliflozyną w dawce $10 \mathrm{mg}$ raz/dobę lub przyjmujących placebo. Wszystkich chorych poddano standardowej terapii HFrEF. Pierwszorzędowym, złożonym punktem końcowym było wystąpienia pierwszego epizodu nasilenia HF (tj. hospitalizacja z tego powodu lub pilna interwencja lekarska wymagająca leczenia dożylnego) lub zgon z przyczyn sercowo-naczyniowych. Trzeba wyjaśnić, że konstrukcja pierwszorzędowego punktu końcowego w tym badaniu różni się od zastosowanej w innych badaniach i poza hospitalizacją z powodu HF zawiera składową interwencji ambulatoryjnej pod postacią dożylnego podania leku. Analiza składowych punktu końcowego wykazała, że przyjmowanie dapagliflozyny obniżało ryzyko zgonu o 17\% oraz ryzyko wystąpienia pierwszego epizodu nasilenia HF o 30\% ( $p<0,05$ dla obu składowych). W populacji DAPA-HF pierwszorzędowy punkt końcowy wystąpił u 386 z 2373 pacjentów (16,3\%) w grupie leczonej dapagliflozyną i u 502 z 2373 pacjentów (21,2\%) w grupie przyjmującej placebo. W badaniu DAPA-HF udokumentowano, że stosowanie dapagliflozyny obniża ryzyko wystąpienia pierwszorzędowego punktu końcowego o 26\% zarówno u chorych na cukrzycę (współczynnik ryzyka [HR, hazard ratio] 0,75; 95-proc. przedział ufności [Cl, confidence interval] 0,63-0,85), jak i pacjentów bez cukrzycy (HR 0,73; 95\% Cl 0,60-0,88). Stosowanie tej flozyny wpływało też korzystnie na jakość życia. Przełom w terapii HFrEF z zastosowaniem dapagliflozyny polega na tym, że po raz pierwszy lek hipoglikemizujący przynosi korzyść kliniczną udokumentowaną w ramach medycyny opartej na dowodach naukowych (EBM, evidence-based medicine) pacjentom bez współistniejącej cukrzycy. 5 maja br. FDA zatwierdziła dapagliflozynę w nowym wskazaniu w celu obniżenia ryzyka zgonu z powodu HF i hospitalizacji z powodu HF u dorosłych z HFrEF w II-IV klasie według New York Heart Association (NYHA) ze współistniejącą cukrzycą typu 2 oraz bez cukrzycy.

Ze względu na mechanizm działania SGLT2i związany ze zwiększeniem wydalania glukozy z moczem (glukozurią) poprzez zahamowanie jej zwrotnego transportu w cewce proksymalnej, któremu towarzyszy natriureza, można nazwać leki z tej grupy nowoczesnymi diuretykami, choć wyniki ograniczenia zdarzeń sercowo-naczyniowych uzyskane podczas terapii SGLT2i wskazują na istotne efekty poza działaniem moczopędnym, o charakterze plejotropowym [7]. Dla SGLT2i postuluje się na drodze hamowania pompy sodowo-wodorowej zmniejszenie uszkodzenia serca, hamowanie procesów przerostu, włóknienia i niekorzystnego remodelingu. Grupa ta zmienia szlak metaboliczny komórki mięśnia sercowego, wykorzystując oksydację bogatszych energetycznie ciał ketonowych zamiast wolnych kwasów tłuszczowych lub glukozy, co poprawia funkcjonowanie i wydajność pracy mięśnia sercowego. Z innych korzystnych działań SGLT2i należy wymienić nefroprotekcję, zmniejszenie masy ciała, a także obniżenie ciśnienia tętniczego. Leki z tej grupy wykazują słabe działanie hipoglikemiczne, nie stwarzają ryzyka hipoglikemii, a ryzyko obniżenia estymowanego współczynnika filtracji kłębuszkowej (eGFR, estimated glomerular filtration rate) jest niewielkie (3-5 ml/min) i zazwyczaj występuje na początku terapii. Wydaje się, że jednoczesne stosowanie diuretyków oraz SGLT2i w okresie długoterminowym lub przy intensywnym leczeniu moczopędnym może sprzyjać hiponatremii, dlatego może być konieczna modyfikacja leczenia. Należy również pamiętać o przestrzeganiu zasad higieny okolic intymnych podczas stosowania SGLT2i oraz w przypadku objawów kwasicy ketonowej (nudności, wymioty, bóle brzucha, jadłowstręt, splątanie), będącej możliwym, aczkolwiek rzadkim, powikłaniem po SGLT2i.

\section{ARNI - inhibitor receptora angiotensyny i neprylizyny}

Kolejną nowością w terapii HFrEF jest sakubitril/walsartan w okresie przedwypisowym dla chorych hospitalizowanych z powodu zaostrzenia HF. Warto przypomnieć, że inhibitory 
receptora angiotensyny i neprilizyny (ARNI, angiotensin receptor neprilysin inhibitor) wprowadzono do terapii HFrEF w 2016 roku po przełomowych wynikach badania PARADIGM-HF dotyczących populacji ambulatoryjnej ze stabilną HFrEF [2]. Od tego czasu ukazało się wiele subanaliz badania PARADIGM-HF, w których w odniesieniu do leku sakubitril/walsartan udokumentowano przedłużenie życia w HFrEF [8], obniżenie ryzyka zapadalności na cukrzyce wymagającą insulinoterapii [9], niższe ryzyko ciężkiej hiperpotasemii (> 6,0 mmol/l) i pogorszenia funkcji nerek w porównaniu z leczeniem enalaprilem i antagonistami receptora AT1 dla angiotensyny II (ARB, angiotensin AT1 receptor blockers) i antagonistami receptora mineralokortykoidowego (MRA, mineralocorticoid receptor antagonists) $[10,11]$. Natomiast w nowych badaniach - TRANSITION [12] i PIONEER-HF [13] - udokumentowano korzyść kliniczną z terapii ARNI u pacjentów hospitalizowanych z powodu ostrej manifestacji HFrEF (de novo lub zaostrzenie przewlekłej) w okresie przedwypisowym oraz w pierwszych tygodniach po wypisaniu, czyli w okresie vulnerable phase. Vulnerable phase charakteryzuje się wysokim ryzykiem rehospitalizacji z powodu zaostrzeń HF, zgonów oraz nadmiernej aktywacji neurohormonalnej. W obu badaniach uczestniczyła dość liczna grupa chorych z HF de novo w badaniu PIONEER-HF - 35\%, a w badaniu TRANSITION - 28,9\%.

W badaniach TRANSITION i PIONEER-HF udokumentowano, że rozpoczęcie terapii ARNI w okresie przedwypisowym jest bezpieczne i wiąże się z wczesną i utrzymującą się poprawą w zakresie obniżenia ryzyka wystąpienia poważnych zdarzeń klinicznych oraz stężeń biomarkerów (N-końcowy fragment propeptydu natriuretycznego typu B [NT-proBNP, N-terminal pro-B-type natriuretic peptide], troponina oznaczana metodą wysokoczułą [hsTnT, high-sensitivity troponin T]), wskazując na patofizjologiczne korzyści w populacji z HFrEF $[12,13]$.

Wobec braku terapii poprawiających przeżycie w ostrej HF wyniki badań TRANSITION oraz PIONEER-HF zyskały istotne znaczenie i zostały uwzględnione w konsensusie w postaci następującego zalecenia: rozpoczęcie terapii lekiem sakubitril/walsartan można rozważyć zamiast ACEI czy ARB po uzyskaniu stabilności hemodynamicznej u pacjentów hospitalizowanych z powodu ostrej manifestacji HF (de novo lub zaostrzenie przewlekłej) w celu poprawy rokowania w okresie krótkoterminowym i dla ułatwienia prowadzenia leczenia (uniknięcie leczenia ACEI z zasadą zwiększania dawek i przełączania na ARNI) [1]. Dla rozpoczęcia terapii ARNI w okresie przedwypisowym istotne są kryteria stabilności hemodynamicznej, które określono w wyżej wymienionych badaniach, tj. przez co najmniej $6 \mathrm{~h}$ brak podaży dożylnej leków moczopędnych i rozszerzających naczynia oraz $24 \mathrm{~h}$ bez podawania dożylnych leków inotropowych oraz skurczowe ciśnienie tętnicze co najmniej
100 mm Hg bez objawowego niedociśnienia tętniczego. Lek okazał się bezpieczny w tej grupie chorych.

\section{Strategie farmakoterapii w HFrEF}

W konsensusie podkreślono rolę strategii poprawiających przestrzeganie wytycznych dotyczących stosowania farmakoterapii w HF. Ciagle aktualnym problemem pozostaje nieoptymalne wykorzystywanie istniejących metod farmakoterapii w praktyce klinicznej. Duża część chorych z HFrEF nie jest poddana odpowiedniej farmakoterapii w adekwatnych dawkach, a warto przypomnieć, że w przypadku terapii modyfikujących przebieg HF o udokumentowanej skuteczności największe korzyści kliniczne są osiągane, gdy stosuje się terapeutyczne dawki docelowe. U części chorych nie jest również prowadzona optymalizacja farmakoterapii przed zastosowaniem elektroterapii. Natomiast wykorzystanie urządzeń wszczepialnych jest zbyt małe w porównaniu z istniejącymi potrzebami. W konsensusie przytoczono wyniki dwóch badań z obszaru przestrzegania wytycznych stosowania farmakoterapii - rejestr QUALIFY przeprowadzony u pacjentów ambulatoryjnych ze stabilną HFrEF $[14,15]$ oraz badanie BIOSTAT-CHF w populacji po przebytym zaostrzeniu HF [16]. Dane dotyczące polskiej populacji rejestru QUALIFY opublikowano w „Polskim Archiwum Medycyny Wewnętrznej" [17]. Udokumentowano, że przestrzeganie wytycznych na dobrym poziomie, czyli standardowa terapia ACEI/lekami beta-adrenolitycznymi/MRA oraz iwabradyna jeśli wskazana, z uzyskaniem co najmniej $50 \%$ rekomendowanych dawek docelowych, prowadziło do poprawy rokowania (ryc. 1).

Natomiast w badaniu BIOSTAT-CHF [16], które było zaprojektowane do oceny zwiększania dawki ACEI/ /ARB i/lub beta-adrenolityku, podobnie jak w QUALIFY, udokumentowano wyższe ryzyko zgonu i/lub hospitalizacji z powodu HF u pacjentów przyjmujących mniejsze dawki, tj. mniej niż 50\% docelowej dawki terapeutycznej. Wyniki powyższych badań jednoznacznie wskazują, że optymalizacja terapii jest właściwą drogą do poprawy rokowania i uniknięcia wielu hospitalizacji w populacji z HFrEF.

Poszukując najlepszych rozwiązań terapeutycznych służących poprawie rokowania pacjenta z HFrEF, należy wspomnieć analizę sieciową Komajdy i wsp. [18] z wytypowaniem najbardziej efektywnych połączeń lekowych. W tabeli 1 przedstawiono schematy leczenia i udokumentowane efekty kliniczne w zakresie obniżenia ryzyka wystąpienia śmiertelności całkowitej, zgonu z przyczyn sercowo-naczyniowych, hospitalizacji z jakiejkolwiek przyczyny i hospitalizacji z powodu HF. Z ograniczeń tej analizy należy wymienić brak analiz innych połączeń lekowych, wśród których najbardziej interesującym wydaje się uwzględnienie w schemacie 


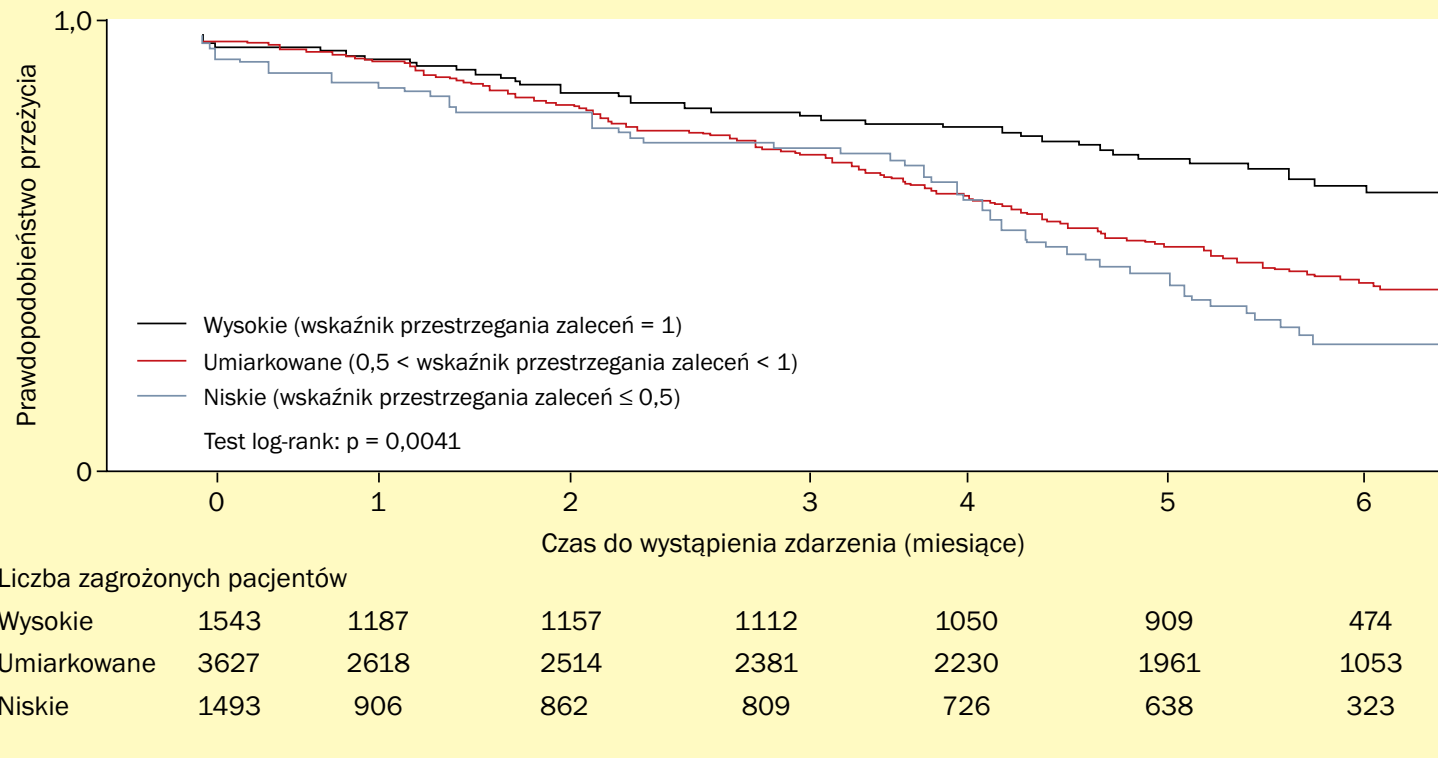

Rycina 1. Przestrzeganie zaleceń w zakresie farmakoterapii w niewydolności serca z obniżoną frakcją wyrzutową lewej komory a prawdopodobieństwo przeżycia na podstawie rejestru QUALIFY (na podstawie [15])

Tabela 1. Najbardziej efektywne terapie według analizy sieciowej Komajdy i wsp. [18]

\begin{tabular}{lcccc} 
Terapia & $\begin{array}{c}\text { Obniżenie ryzyka zgonu } \\
(\%)\end{array}$ & $\begin{array}{c}\text { Obniżenie ryzyka zgonu } \\
\text { sercowo-naczyniowego } \\
(\%)\end{array}$ & $\begin{array}{c}\text { Obniżenie ryzyka } \\
\text { hospitalizacji (\%) }\end{array}$ & $\begin{array}{c}\text { Obniżenie ryzyka } \\
\text { hospitalizacji } \\
\text { z powodu HF (\%) }\end{array}$ \\
\hline $\begin{array}{l}\text { ARNI + } \beta \text {-adrenolityk } \\
+ \text { MRA }\end{array}$ & 62 & 64 & 42 & 75 \\
$\begin{array}{l}\text { ACEI + } \beta \text {-adrenolityk } \\
+ \text { MRA + iwabradyna }\end{array}$ & 59 & 59 & 42 & 73 \\
\hline
\end{tabular}

ARNI (angiotensin receptor neprilysin inhibitor) - antagonista receptora angiotensyny i inhibitor neprylizyny; MRA (mineralocorticoid receptor antagonists) - antagoniści receptora mineralokortykoidowego; ACEl (angiotensin-converting enzyme inhibitors) - inhibitory konwertazy angiotensyny

połączenia ARNI + iwabradyna, ale jest to zagadnienie wymagające przeprowadzenia nowych badań.

\section{Elektroterapia, interwencje i inne terapie}

W konsensusie [1] znalazły się również informacje na temat:

- wszczepialnego kardiowertera-defibrylatora (ICD, implantable cardioverter-defibrillator) i wyników badania DANISH, które powodują, że z większym dystansem niż wcześniej w aspekcie kwalifikacji do ICD postrzega się populację po 70. roku życia z HFrEF o etiologii nieniedokrwiennej i pacjentów obciążonych chorobami towarzyszącymi, które zwiększają ryzyko wystąpienia zgonu z innej przyczyny niż nagła śmierć sercowa. Najwięcej korzyści w badaniu DANISH odnieśli pacjenci z etiologią niedokrwienną HFrEF w młodszych grupach wiekowych (< 59 lat), u których wszczepienie ICD zmniejszyło śmiertelność o blisko połowę;
- ablacji migotania przedsionków (można rozważyć), wskazując na strategię leczenia inwazyjnego (izolacja żył płucnych) jako lepszą niż farmakologiczna u pacjentów z HFrEF i objawami napadowej arytmii, natomiast w przypadku przetrwałego migotania przedsionków ablację można rozważyć u chorych z HFrEF, u których arytmia zaostrza objawy HF, przy wysokim prawdopodobieństwie utrzymania rytmu zatokowego oraz planach terapii resynchronizującej (CRT, cardiac resynchronisation therapy) lub obecności urządzenia. W badaniach CASTLE-AF i CABANA, choć budzą kontrowersje głównie ze względu na ich konstrukcję, z pewnością udokumentowano poprawę dystansu w teście 6-minutowego chodu (6MWT, 6 minute walk test) i jakości życia u pacjentów z rytmem zatokowym po ablacji. Natomiast ablację węzła przedsionkowo-komorowego zazwyczaj z dwukomorową stymulacją można rozważyć w sytuacji nieskutecznej lub niemożliwej do wykonania izolacji żył 
płucnych, jeśli napady migotania przedsionków prowokują nasilenie HF;

- zastosowania riwaroksabanu w dawce 2 razy $2,5 \mathrm{mg}$ dodanego do terapii kwasu acetylosalicylowego można rozważyć w ambulatoryjnej populacji w I-II klasie NYHA z EF > 30\% w celu zmniejszenia częstości udarów mózgu lub przemijającego niedokrwienia mózgu oraz zgonów sercowo-naczyniowych, nie odnotowano korzyści z tej terapii dla poprawy rokowania w HF czy redukcji hospitalizacji z powodu HF (wyniki badania COMMANDER-HF);

- czynnościowa niedomykalność mitralna (FMR, functional mitral regurgitation) w świetle wyników COAPT i MITRA-FR (MitraClip) oraz PRIME (sakubitril/walsartan): badania z Mitraclip różnią się w zakresie populacji i nie powinny być porównywane, ale przeprowadzenie ich pozwoliło zidentyfikować chorych odnoszących korzyść z zabiegu Mitraclip (kryteria COAPT) (można rozważyć), natomiast badanie PRIME choć przeprowadzone na stosunkowo małej populacji liczącej 118 pacjentów, udokumentowało podczas terapii ARNI korzystny odwrotny remodeling w ocenie echokardiograficznej ze zmniejszeniem efektywnego pola FMR. Wyniki badania PRIME wskazują na konieczność optymalizacji farmakoterapii pacjentów z HFrEF i współistniejącą FMR, przed ostateczną kwalifikacją do działań inwazyjnych;

- leków wiążących potas (Patiromer i ZS-9): eksperci wskazują, że u chorych z HFrEF niezależnie od współistniejącej przewlekłej choroby nerek, można rozważyć leki wiążące potas, jeśli wobec hiperkaliemii nie jest możliwe zastosowanie MRA oraz innych inhibitorów RAAS lub uzyskanie dawki terapeutycznej docelowej MRA. Patiromer to niewchłanialny polimer ze zdolnością wymiany kationów, który jako przeciwjon zawiera kompleks wapń-sorbitol, w przeciwieństwie do sodu, który zawiera ZS-9. Patiromer zwiększa wydalanie potasu w kale poprzez wiązanie potasu $\mathrm{w}$ świetle przewodu pokarmowego. Lek w grupie chorych z HF przebadano w badaniu PEARL-HF, w którym udokumentowano, ze więcej chorych mogło stosować spironolakton w dawce $50 \mathrm{mg}$ w grupie nowego leku niż w grupie placebo ( $91 \%$ vs. $74 \%, p=0,019)$. Dla możliwości pełnego leczenia HFrEF lekami modyfikującymi przebieg choroby leki wiążące potas mają niewątpliwie istotne znaczenie kliniczne. Aktualnie trwają badania dla oceny poprawy rokowania w HFrEF podczas terapii tą grupą leków;

- modulacja kurczliwości mięśnia sercowego - metoda przeznaczona dla chorych z HFrEF (EF 25-45\%) i z wąskim QRS poniżej 130 ms (można rozważyć). Na obecnym etapie badań udokumentowano, że poprawia jakość życia, wymaga oceny wpływu na chorobowość i umieralność. Procedura nie jest refundowana w Polsce;

- urządzeń wspomagających pracę komór - eksperci wskazują HeartMate 3 (należy rozważyć) zamiast HeartMate 2 ze względu na większy odsetek 2-letnich przeżyć i mniejszą liczbę zdarzeń niepożądanych. Dostępność do tego typu terapii w Polsce jest jednak ograniczona i możliwa jedynie w ośrodkach najwyższej referencyjności.

\section{Wnioski}

Podsumowując aktualny stan wiedzy, w kolejnych wytycznych ESC w 2021 roku zapewne czeka nas zmiana standardowej terapii HFrEF z wyższym pozycjonowaniem ARNI, włączenie SGLT2i do algorytmu postępowania terapeutycznego oraz preferowanie najbardziej efektywnych połączeń terapii w celu poprawy rokowania z uwzględnieniem przestrzegania zaleceń (dawki terapeutyczne docelowe) i budowanie zespołów wielospecjalistycznej opieki. Być może pojawią się w wytycznych również nowe inne terapie, dla których badania zostały aktualnie zakończone.

\section{Konflikt interesów}

Badania kliniczne i wykłady dla firm Novartis, Boehringer Ingelheim, Servier, Astra.

\section{Abstract}

The last years it is a good time in heart failure (HF) for innovative therapy. The results of new trials which were published after the last 2016 guidelines for HF need the systematic approach and provide evidence-based guidance for clinical practice. For that reason in the last year 2019 the experts of Heart Failure Association (HFA) European Society of Cardiology published the consensus. The present article summarized the main issues regarding heart failure with reduced ejection fraction together with comment based on the HFA expert consensus.

Key words: heart failure with reduced ejection fraction

Folia Cardiologica 2020; 15, 2: 176-181 


\section{Piśmiennictwo}

1. Seferovic PM, Ponikowski P, Anker SD, et al. Clinical practice update on heart failure 2019: pharmacotherapy, procedures, devices and patient management. An expert consensus meeting report of the Heart Failure Association of the European Society of Cardiology. Eur J Heart Fail. 2019; 21(10): 1169-1186, doi: 10.1002/ejhf.1531, indexed in Pubmed: 31129923.

2. Ponikowski P, Voors AA, Anker SD, et al. Authors/Task Force Members, Document Reviewers. 2016 ESC Guidelines for the diagnosis and treatment of acute and chronic heart failure: the Task Force for the diagnosis and treatment of acute and chronic heart failure of the European Society of Cardiology (ESC). Developed with the special contribution of the Heart Failure Association (HFA) of the ESC. Eur J Heart Fail. 2016; 18(8): 891-975, doi: 10.1002/ejhf.592, indexed in Pubmed: 27207191.

3. Inzucchi SE, Kosiborod M, Fitchett D, et al. Improvement in cardiovascular outcomes with empagliflozin is independent of glycemic control. Circulation. 2018; 138(17): 1904-1907, doi: 10.1161/CIRCULATIONAHA.118.035759, indexed in Pubmed: 30354665.

4. Fitchett D, Inzucchi SE, Cannon CP, et al. Empagliflozin reduced mortality and hospitalization for heart failure across the spectrum of cardiovascular risk in the EMPA-REG OUTCOME trial. Circulation. 2019; 139(11): 1384-1395, doi: 10.1161/CIRCULATIONAHA.118.037778, indexed in Pubmed: 30586757.

5. Claggett B, Lachin JM, Hantel S, et al. Long-term benefit of empagliflozin on life expectancy in patients with type 2 diabetes mellitus and established cardiovascular disease. Circulation. 2018; 138(15): 1599-1601, doi: 10.1161/CIRCULATIONAHA.118.033810, indexed in Pubmed: 30354516.

6. McMurray JJV, Solomon SD, Inzucchi SE, et al. DAPA-HF Trial Committees and Investigators. Dapagliflozin in patients with heart failure and reduced ejection fraction. N Engl J Med. 2019; 381(21): 1995-2008, doi: 10.1056/NEJMoa1911303, indexed in Pubmed: 31535829.

7. Vaduganathan M, Claggett BL, Solomon SD. How do SGLT-2 inhibitors work to prevent heart failure? JACC Heart Fail. 2020; 8(1): 67-69, doi: 10.1016/j.jchf.2019.11.009, indexed in Pubmed: 31896418.

8. Claggett B, Packer M, McMurray JJV, et al. PARADIGM-HF Investigators. Estimating the long-term treatment benefits of sacubitril-valsartan. N Engl J Med. 2015; 373(23): 2289-2290, doi: 10.1056/ /NEJMc1509753, indexed in Pubmed: 26630151.

9. Seferovic JP, Claggett B, Seidelmann SB, et al. Effect of sacubitril/ /valsartan versus enalapril on glycaemic control in patients with heart failure and diabetes: a post-hoc analysis from the PARADIGM-HF trial. Lancet Diabetes Endocrinol. 2017; 5(5): 333-340, doi: 10.1016/ /S2213-8587(17)30087-6, indexed in Pubmed: 28330649.
10. Desai AS, Vardeny 0, Claggett B, et al. Reduced risk of hyperkalemia during treatment of heart failure with mineralocorticoid receptor antagonists by use of sacubitril/valsartan compared with enalapril: a secondary analysis of the PARADIGM-HF trial. JAMA Cardiol. 2017; 2(1): 79-85, doi: 10.1001/jamacardio.2016.4733, indexed in Pubmed: 27842179.

11. Damman K, Gori M, Claggett B, et al. Renal effects and associated outcomes during angiotensin-neprilysin inhibition in heart failure. JACC Heart Fail. 2018; 6(6): 489-498, doi: 10.1016/j.jchf.2018.02.004, indexed in Pubmed: 29655829.

12. Wachter R, Senni M, Belohlavek J, et al. TRANSITION Investigators. Initiation of sacubitril/valsartan in haemodynamically stabilised heart failure patients in hospital or early after discharge: primary results of the randomised TRANSITION study. Eur J Heart Fail. 2019; 21(8): 998-1007, doi: 10.1002/ejhf.1498, indexed in Pubmed: 31134724.

13. Velazquez EJ, Morrow DA, DeVore AD, et al. PIONEER-HF Investigators. Angiotensin-neprilysin inhibition in acute decompensated heart failure. N Engl J Med. 2019; 380(6): 539-548, doi: 10.1056/ /NEJMoa1812851, indexed in Pubmed: 30415601.

14. Komajda M, Anker SD, Cowie MR, et al. QUALIFY Investigators. Physicians' adherence to guideline-recommended medications in heart failure with reduced ejection fraction: data from the QUALIFY global survey. Eur J Heart Fail. 2016; 18(5): 514-522, doi: 10.1002/ /ejhf.510, indexed in Pubmed: 27095461.

15. Komajda M, Cowie MR, Tavazzi L, et al. QUALIFY Investigators. Physicians' guideline adherence is associated with better prognosis in outpatients with heart failure with reduced ejection fraction: the QUALIFY international registry. Eur J Heart Fail. 2017; 19(11): 1414-1423, doi: 10.1002/ejhf.887, indexed in Pubmed: 28463464.

16. Ouwerkerk W, Voors AA, Anker SD, et al. Determinants and clinical outcome of uptitration of ACE-inhibitors and beta-blockers in patients with heart failure: a prospective European study. Eur Heart J. 2017; 38(24): 1883-1890, doi: 10.1093/eurheartj/ehx026, indexed in Pubmed: 28329163.

17. Opolski G, Ozierański K, Lelonek M, et al. Adherence to the guidelines on the management of systolic heart failure in ambulatory care in Poland. Data from the international QUALIFY survey. Pol Arch Intern Med. 2017; 127(10): 657-665, doi: 10.20452/pamw.4083, indexed in Pubmed: 28786405.

18. Komajda M, Böhm M, Borer JS, et al. Incremental benefit of drug therapies for chronic heart failure with reduced ejection fraction: a network meta-analysis. Eur J Heart Fail. 2018; 20(9): 1315-1322, doi: 10.1002/ejhf.1234, indexed in Pubmed: 29806165. 